\title{
PEMBELAJARAN MATEMATIKA MENGGUNAKAN MODEL LEARNING CYCLE 5E UNTUK MENINGKATKAN KEMAMPUAN PENALARAN MATEMATIS SISWA SMP 30 PADANG
}

\author{
MATHEMATICAL LEARNING USING LEARNING CYCLE 5E \\ MODEL TO IMPROVE MATHEMATICAL REASONING ABILITY IN \\ SMP 30 PADANG
}

\section{Pitriati}

SMPN 30 Padang

E-mail: pitriatiamir@gmail.com

Diterima: 17 Mei 2019. Disetujui: 9 Juli 2019. Dipublikasikan: 31 Juli 2019

\begin{abstract}
This research is motivated by the low activity and competitiveness of students in working on mathematical questions and the lack of reasoning abilities of students in carrying out the tasks given. The purpose of this study is to examine the improvement of reasoning abilities of students who have learned the Learning Cycle 5e model. Learning Cycle is a conceptual framework that is used as a guide in conducting student-centered learning processes. This type of research is classroom action research conducted collaborating between researchers and mathematics teachers. The subjects in this study were class IX.I SMPN 30 Padang in the 2017/2017 academic year, totaling 32 people. The data method used in this study is observation, field notes and documentation. Data analysis techniques were carried out in qualitative and quantitative descriptive. The results of this class action research showed an increase in student activity so that there was an increase in mathematical reasoning abilities of students far increased compared to students in learning that were not given Learning Cycle $5 e$.
\end{abstract}

Keywords: mathematics, action research, learning cycle 5e, reasoning ability

Abstrak: Penelitian ini dilatarbelakangi oleh rendahnya aktivitas dan daya saing siswa dalam mengerjakan soal-soal matematika serta kurangnya kemampuan penalaran siswa dalam mengerjakan tugas-tugas yang diberikan. Tujuan penelitian ini untuk menelaah peningkatan kemampuan penalaran siswa yang memperoleh pembelajaran model Learning Cycle 5e. Learning Cycle adalah suatu kerangka konseptual yang digunakan sebagai pedoman dalam melakukan proses pembelajaran yang terpusat pada siswa. Jenis penelitian ini adalah penelitian tidakan kelas yang dilakukan kolaburasi antara peneliti dengan guru matematika. Subjek dalam penelitian ini adalah siswa kelas IX.1 SMPN 30 Padang tahun pelajaran 2017/2017 yang berjumlah 32 orang. Metode data yang digunakan pada penelitian ini adalah observasi, catatan lapangan dan dokumentasi. Teknik analisis data dilakukan secara deskriptif kualitatif dan kuantitatif. Hasil penelitian tindakan kelas ini menunjukan peningkatan keaktifan siswa sehingga terjadi peningkatan kemampuan penalaran matematis siswa jauh meningkat dibandingkan dengan siswa pada pembelajaran yang tidak diberikan Learning Cycle 5e.

(C) 2019 Unit Riset dan Publikasi Ilmiah FTK UIN Raden Intan Lampung

Kata Kunci: matematika, PTK, learning cycle 5e, kemampuan penalaran

\section{PENDAHULUAN}

Pendidikan memegang peranan yang sangat penting dalam meningkatkan kualitas sumber daya manusia untuk menghadapi perkembangan ilmu teknologi yang terjadi secara terus menerus. Salah satu usaha yang perlu dilakukan dalam meningkatkan sumber daya manusia, melalui jalur pendidikan, adalah meningkatkan mutu pendidikan bidang studi matematika. 
Pembelajaran matematika merupakan salah satu pembelajaran yang mendasar untuk pencapaian ilmu lainnya. Fungsi matematika menjadi sangat penting dalam perkembangan ilmu pengetahuan. Oleh karena itu, pemerintah selalu berusaha meningkatkan kualitas dan mutu pendidikan terutama bidang studi matematika (Bakhtiar, 2004)

Matematika juga dapat menjelaskan dan menyelesaikan permasalahan dalam kehidupan sehari-hari secara cepat. Sesuai dengan tujuan pembelajaran matematika yaitu: a) belajar untuk berkomunikasi; b) belajar untuk bernalar; c) belajar untuk memecahkan masalah; d) belajar untuk mengaitkan ide; dan e) belajar untuk merepresentasikan ide-ide (National Council of Teacher of Mathematics, 2000). Kompetensi tersebut diperlukan agar siswa dapat memiliki kemampuan memperoleh, mengelola, dan memanfaatkan informasi untuk bertahan hidup pada keadaan yang selalu berubah, tidak pasti, dan kompetitif.

Kemampuan penalaran matematis haruslah mampu dimiliki oleh siswa setingkat SMP/MTs. Hendaknya mampu bernalar yang deduktif diantaranya melaksanakan perhitungan berdasarkan aturan atau rumus tertentu dan menarik kesimpulan logis (penalaran logis). Penalaran adalah proses berfikir untuk menarik kesimpulan berupa pengetahuan baru dengan menerapkan logika deduktif atau induktif atau keduanya (Akhadiah dkk, 2010).

Seseorang yang mampu mengembangkan nalarnya akan cenderung lebih tanggap terhadap permasalahan disekitarnya. Kemampuan penalaran matematis juga penting untuk membantu siswa mengemukakan pendapat maupun idenya secara runtut dan logis. Siswa akan mampu menilai sesuatu secara kritis dan objektif, dengan tepat serta mampu meminimalisir gejala-gejala pada dirinya yang dapat membuat kemampuan matematikanya rendah.
Beberapa keuntungan apabila siswa diperkenalkan dengan penalaran, yaitu: Siswa akan terbantu dalam memahami proses yang telah disiapkan, menimbulkan rasa percaya diri dan menghilangkan rasa takut, dan membuat siswa lebih aktif. Pembelajaran yang lebih menekankan pada aktivitas penalaran dapat mencapai prestasi siswa yang tinggi (Dahlan, 2004).

Sumarmo

(Siregar,

2011)

menemukan bahwa keadaan skor kemampuan siswa dalam penalaran matematis masih rendah. Sebagai contoh pembelajaran matematika di Jepang dan Korea yang lebih menekankan pada aspek penalaran mampu menghasilkan siswa berprestasi tinggi dalam tes matematika yang dilakukan oleh The Third International Mathematics and Science Study (TIMSS, 2003).

Beberapa hal yang diperkirakan menjadi penyebab kurang berkembangnya kemampuan penalaran matematis siswa, diantaranya adalah pelaksanaan pembelajaran dengan model pembelajaran strategi yang tidak disesuaikan dengan materi pelajaran dan karakter siswa.

Selama ini pelaksanaan pembelajaran lebih bersifat mekanistik, proses pembelajaran lebih banyak menekankan pada aspek doing tetapi kurang menekankan pada aspek thinking. Apa yang diajarkan dikelas lebih banyak berkaitan dengan masalah keterampilan manipulatif atau bagaimana mengerjakan sesuatu tetapi kurang berkaitan dengan mengapa demikian dan apa aplikasinya. Dengan kata lain siswa belajar memahami hanya dalam bentuk hafalan saja (memorizing). Begitu juga model pembelajaran yang digunakan hanyalah dalam bentuk konvensional tidak mencocokkan dengan materi yang akan di berikan kepada siswa. Biasanya siswa lebih banyak monoton,pasif ketimbang aktif. Siswa pada umumnya menerima dengan mendengar apa yang disampaikan guru dalam bentuk demonstrasi, dimana guru yang dominan aktif sedangkan siswa 
pasif. Siswa tidak banyak mendapat pengalaman belajar dan juga mengeluarkan ide-idenya untuk mengembangkan kemampuan penalaran matematisnya.

Berdasarkan pengalaman peneliti mengajar di kelas IX.1, diperoleh hasil belajar matematika siswa kelas IX.1, tergolong rendah. Hal ini dapat dilihat dari penilaian harian pertama yang diperoleh adalah sebesar 42,25. Rendahnya hasil belajar tersebut disebabkan karena siswa mengalami kesulitan dalam memahami konsep matematika yang dipelajarinya. Banyak faktor yang menjadi penyebabnya sehingga siswa belum mampu memahami dengan baik konsep matematika yang diajarkan oleh guru. Salah satu faktor penyebabnya adalah model pembelajaran yang digunakan kurang tepat dalam menyajikan materi matematika sehingga belum dapat memotivasi siswa untuk belajar secara aktif dan belum mampu meningkatkan pemahaman mereka.

Hal ini jika dibiarkan terus berkembang, maka prinsip dan standar yang tertuang dalam NCTM (1989) serta tujuan pelajaran matematika di SMP tidak akan tercapai. Dalam hal ini peranan guru harus mampu melakukan-agar siswa tidak jenuh. Biasanya guru selalu sebagai pusat (center) dalam proses belajar mengajar, melainkan guru hanya sebagai fasilitator dimana siswalah yang menjadi pusat dalam proses belajar mengajar yang disebut dengan Student-Centered.

Siswa yang aktif dalam proses pembelajaran tentunya dapat menjadi salah satu solusi alternatif untuk mengatasi masalah rendahnya kemampuan penalaran matematis siswa terhadap pelajaran matematika. Salah satu cara yang dapat membuat siswa aktif tentunya dengan cara memilih modelmodel pembelajaran yang tepat atau strategi yang diguanakan. Menerapkan model pembelajaran Learning Cycle 5E dapat membuat siswa lebih aktif. Model Learning Cycle $5 E$ merupakan salah satu model pembelajaran yang memberikan kesempatan kepada siswa untuk mengoptimalkan dan mengembangkan daya nalar mereka masing-masing. Learning Cycle 5E merupakan salah satu model pembelajaran yang menuntun siswa untuk menemukan sendiri konsep yang dipelajari, sedangkan adalah suatu strategi yang dilakukan agar masingmasing siswa siap bertanggung jawab terhadap apa yang telah dipelajarinya.

Model pembelajaran ini merupakan rangkaian dari tahap-tahap kegiatan (fase) yang diorganisasikan sedemikian rupa sehingga siswa dapat menguasai kompetensi-kompetensi yang harus dicapai dalam pembelajaran dengan jalan berperan aktif,guru hanya sebagai fasilitator. Secara umum dalam model pembelajaran Learning Cycle $5 E$ terdapat rangkaian kegiatan yang dilakukan secara tepat dan teratur.

Model Learning Cycle 5E dapat membuat siswa bebas berimajinatif dan berpikir kreatif dalam bentuk gambar, simbol, lisan, grafik maupun teks tertulis, sehingga tidak menghafal konsep semata. Model pembelajaran ini setidaknya akan mampu melahirkan kemampuan siswa dalam bernalar secara matematis.

Gambaran umum di atas terlihat bahwa model Learning Cycle 5E serta sangat cocok untuk mengatasi masalah proses pembelajaran yang terjadi di sekolah agar pencapaian kemampuan penalaran matematis siswa dapat meningkat. Penulis menerapkan model Learning Cycle $5 E$ pada pembelajaran matematika untuk tingkat SMP/MTs, karena dapat meningkatkan keaktifan siswa sehingga meningkatkan hasil belajarnya.

Berdasarkan permasalahan yang telah diuraikan, peneliti tertarik untuk melakukan penelitian tindakan kelas dengan judul "Pembelajaran Matematika Menggunakan Model Learning Cycle 5E Untuk Meningkatkan Kemampuan 
Penalaran Matematis Siswa SMP Padang"

\section{LANDASAN TEORI}

Pembelajaran dapat diartikan sebagai kegiatan dimana guru dan siswa saling berinteraksi, membicarakan suatu topik atau melakukan suatu aktivitas, guna mencapai tujuan yang dikehendaki. Pembelajaran merupakan suatu aktivitas belajar yang melibatkan siswa dan guru bersamaan. Proses pembelajaran merupakan suatu sistem (Sanjaya, 2006).

Dalam proses pembelajaran terdapat komponen-komponen yang saling berkaitan, yang tidak terpisahkan satu sama lain dan berjalan secara teratur, saling bergantung, komplementer dan berkesinambungan. Adapun komponenkomponen tersebut yaitu guru dan siswa., Pembelajaran yang efektif artinya, dari posisi guru tercipta mengajar yang efektif, dan dari segi siswa tercipta belajar yang efektif. Dalam hal ini guru berperan sebagai sumber belajar, fasilitator, motivator, pembimbing, pengelola dan evaluator, sedangkan siswa berperan sebagai subjek dan objek belajar (Syafaruddin dan Nasution, 2005).

Matematika sebagai salah satu mata pelajaran yang sangat erat kaitannya dengan lingkungan dan fenomena yang terjadi dalam kehidupan, membutuhkan pembelajaran yang bukan saja menekankan teori pada siswa, tetapi juga diiringi dengan kegiatan penemuan. Hal ini disebabkan oleh matematika yang tidak bisa hanya dengan menjelaskan dan membaca buku saja melainkan diusahakan mengadakan banyak kegiatan praktik sesuai materi yang diajarkan. Hanya sebagian siswa yang bisa menangkap pelajaran ini karena mereka dapat membayangkan fenomena yang dijelaskan dalam buku secara abstrak maupun nyata. Sebagian siswa sulit menguasai pelajaran tidak dapat membayangkannya dengan jelas sehingga perlu diadakan kegiatan praktik untuk meningkatkan pemahaman siswa. Hal ini sesuai dengan pendapat ahli menyatakan slogan "belajar dengan melakukan (learning by doing)" dan identik dengan pepatah kuno dari Cina yang menyatakan: Apa yang saya dengar, saya lupakan; apa yang saya lihat, saya ingat; dan apa yang saya lakukan, saya pahami. Sophocles (Warsono dan Hariyanto, 2012).

Jadi kesimpulan pembelajaran matematika merupakan suatu proses belajar dimana siswa lebih banyak melakukan kegiatan melalui pengalaman. Pembelajaran diharapkan dapat menjadi modal pendukung dari mata pelajaran dan mengembangkan kemampuan bernalarnya, serta dapat mengembangkannya lebih lanjut dalam kehidupan sehari-hari.

\section{Model Learning Cycle 5E}

Learning Cycle adalah suatu kerangka konseptual yang digunakan sebagai pedoman dalam melakukan proses pembelajaran yang terpusat pada siswa (student centered). Model pembelajaran pertama kali diperkenalkan oleh Robert Karplus. Learning Cycle merupakan rangkaian dari tahap-tahap kegiatan (fase) yang diorganisasikan sedemikian rupa sehingga siswa dapat menguasai kompetensi-kompetensi yang harus dicapai dalam pembelajaran dengan jalan berperan aktif (Wena, 2008).

Model Learning Cycle merupakan salah satu model pembelajaran yang memberikan kesempatan kepada siswa untuk mengoptimalkan dan mengembangkan daya nalar mereka masing-masing dan menuntun siswa untuk menemukan sendiri konsep yang dipelajari.

Learning Cycle $5 E$ pada awalnya terdiri dari 3 fase, yaitu Fase eksplorasi (exploration), siswa diberi kesempatan untuk memanfaatkan panca inderanya semaksimal mungkin dalam mendiskusikan sebuah fenomena. Fase pengenalan konsep (concept introduction), diharapkan terjadi proses menuju keseimbangan antara konsep-konsep yang telah dimiliki 
siswa dengan konsep-konsep yang baru dipelajari. Terakhir fase aplikasi konsep (concept aplication), siswa diajak menerapkan pemahaman konsepnya melalui kegiatan seperti mengerjakan latihan (Wena, 2008).

\section{Bahan Ajar}

Bahan ajar memiliki peranan yang cukup penting dalam proses pembelajaran. Bahan ajar dapat dijadikan pedoman bagi guru dan siswa dalam kegiatan pembelajaran di kelas. Selain itu bahan ajar juga dapat dijadikan acuan bagi siswa dalam pencapaian kompetensi yang diharapkan setelah proses pembelajaran berlangsung. Karena pada dasarnya bahan ajar memuat substansi materi dari kompetensi yang harus dikuasai oleh siswa. Menurut Depdiknas (2008), sebuah bahan ajar paling tidak mencakup antara lain: a) petunjuk belajar (petunjuk siswa/guru); b) kompetensi yang akan dicapai; c) konten atau isi materi pembelajaran; d) informasi pendukung; e) latihan-latihan; f) petunjuk kerja, dapat berupa lembar kerja; g) evaluasi; h) respon atau balikan terhadap hasil evaluasi.

Bahan ajar yang akan digunakan dalam pembelajaran adalah lembar kegiatan siswa (LKS). LKS adalah salah satu bahan ajar yang sangat berperan dalam proses pembelajaran. Penggunaan LKS dalam pembelajaran dapat memberikan pengalaman yang bermakna bagi siswa. Karena dengan penggunaan LKS akan melibatkan siswa secara aktif untuk menemukan konsep atau pengetahuan baru.

Lembar Kegiatan Siswa (LKS) adalah panduan siswa yang digunakan untuk melakukan kegiatan penyelidikan atau pemecahan masalah. LKS merupakan suatu bahan ajar cetak yang merupakan lembaran-lembaran kertas yang berisi materi, ringkasan, petunjukpetunjuk pengerjaan tugas atau latihan dalam pembelajaran yang harus dikerjakan siswa (Trianto, 2009).

Berdasarkan uraian tersebut dapat disimpulkan Lembar kegiatan siswa (student worksheet) adalah lembaranlembaran yang berisi tugas yang harus dikerjakan oleh siswa. Lembar kegiatan biasanya berupa petunjuk, langkahlangkah untuk menyelesaikan suatu tugas. Tugas yang diperintahkan dalam lembar kegiatan harus jelas KD yang akan dicapainya. Lembar kegiatan dapat digunakan untuk mata pelajaran apa saja. Keuntungan adanya lembar kegiatan adalah bagi guru, memudahkan dalam melaksanakan pembelajaran, bagi siswa akan belajar secara mandiri dan belajar memahami serta menjalankan suatu tugas tertulis.

\section{Kemampuan Penalaran Matematis}

Materi matematika dan penalaran matematis merupakan dua hal yang tidak dapat dipisahkan, yaitu materi matematika dipahami melalui penalaran dan penalaran dipahami dan dilatihkan melalui belajar materi matematika (Depdiknas, 2002). Kemampuan pena-laran matematika adalah kemampuan mengungkapkan argumen yang sangat esensial untuk memahami matematika. Penalaran matematika merupakan suatu kebiasaan pekerjaan otak yang harus dikembangkan secara konsisten dengan menggunakan berbagai macam konteks (Turmudi, 2008).

Secara garis besar penalaran dapat digolongkan dalam dua jenis yaitu penalaran induktif dan penalaran deduktif. Penalaran induktif diartikan sebagai penarikan kesimpulan yang bersifat umum atau khusus berdasarkan data yang teramati.Nilai kebenaran dalam penalaran induktif dapat bersifat benar atau salah.

\section{METODE PENELITIAN}

Jenis penelitian yang akan dilaksanakan adalah penelitian tindakan kelas (classroom action research). 
Penelitian tindakan kelas adalah suatu penelitian yang dilakukan sendiri oleh guru untuk memperbaiki kualitas pembelajaran dengan cara melakukan perubahan-perubahan dan mempelajari akibat dari perubahan itu. Hal ini bertujuan untuk memecahkan langsung masalah yang dihadapi guru di dalam kelas. Dalam penelitian ini masalah tersebut adalah rendahnya motivasi belajar dan kemampuan Penalaran siswa.

Penelitian tindakan kelas ini dilakukan secara kolaboratif. Hal ini didasarkan karena penelitian dilakukan secara berpasangan antara pihak yang melakukan tindakan dan pihak yang mengamati proses jalannya tindakan. Penelitian kolaboratif dikatakan ideal karena adanya upaya untuk mengurangi unsur subjektifitas pengamat serta mutu kecermatan pengamatan yang dilakukan. Dalam penelitian kolaborasi ini pihak yang melakukan tindakan adalah peneliti sendiri, sedangkan yang diminta untuk melakukan pengamatan terhadap berlangsungnya proses tindakan guna mendapatkan data yang lebih akurat adalah teman sejawat dan guru kelas IX. 2 SMPN 30 Padang.

Subjek dalam penelitian ini adalah siswa kelas IX.1SMPN 30 Padang tahun pelajaran 2017/2017 yang berjumlah 32 orang. Kelas ini dipilih sebagai subjek penelitian dikarenakan pada kelas ini ditemukan masalah rendahnya motivasi belajar siswa dan rendahnya kemampuan penalaran matematis siswanya.

Penelitian tindakan kelas ini dilakukan beberapa siklus sampai indikator tingkat ketercapaian terpenuhi. Pada tahap pertama dilakukan tindakan yang mengacu kepada pembelajaran dengan menerapkan model pembelajaran learning cycle 5e. Pada tahap kedua dilakukan tindakan berdasarkan hasil refleksi dari siklus pertama, begitu selanjutnya. Prosedur penelitian ini dilaksanakan tiga tahap yaitu: a) tahap awal untuk melakukan segala persiapan yang diperlukan pada penelitian; b) tahap pelaksanaan; dan c) tahap akhir yang dilakukan adalah analisis data yang didapatkan dari penelitian dan membuat pelaporannya.

\section{Teknik Pengumpulan Data}

Teknik pengumpulan data pada penelitian ini meliputi angket motivasi belajar matematika siswa, catatan lapangan, dan lembar observasi. Angket motivasi belajar matematika siswa ini digunakan untuk mengukur dan mengetahui motivasi belajar matematika siswa SMPN 30 Padang dalam mengikuti pembelajaran menggunakan model leaning sycel 5E. Angket yang digunakan oleh peneliti adalah jenis cheklist. Cheklist yang digunakan menggunakan alternatif jawaban "selalu, sering, jarang, dan tidak pernah".

Pengumpulan data menggunakan angket ini dilakukan oleh guru ketika pembelajaran matematika sudah selesai sebelum kelas dibubarkan, sehingga tidak mengganggu proses pembelajaran. Angket ini diberikan kepada siswa, namun pengisiannya dibimbing oleh guru tanpa ada intervensi.

Catatan lapangan ini memberikan gambaran mengenai keadaan, kejadian, hambatan atau kendala dan masalahmasalah yang ditemui pada setiap pertemuan. Catatan ini dapat digunakan sebagai bahan pertimbangan dalam melakukan refleksi. Catatan lapangan ini memuat data hari dan tanggal pelaksanaan, pokok bahasan/sub pokok bahasan, pertemuan, dan kegiatan yang berlangsung mulai dari awal sampai akhir pembelajaran.

Pada penelitian ini digunakan lembar observasi guru untuk mengamati apakah tindakan yang dilaksanakan sesuai dengan perencanaan tindakan atau tidak dan lembar observasi aktivitas siswa untuk mengamati peningkatan motivasi belajar siswa. Pada penelitian ini guru menggunakan observasi sistematis yang 
menggunakan alat berupa lembar observasi guru dan siswa. Adapun yang diobservasi yaitu: bagaimana aktivitas guru dalam menggunakan model learning sycle $5 \mathrm{E}$ dan bagaimana respon siswa selama mengikuti pembelajaran.

Data yang diperoleh pada penelitian ini adalah data kualitatif dan data kuantitatif. Data kualitatif diperoleh dari hasil observasi dan catatan lapangan. Sedangkan data kuantitatif diperoleh dari angket motivasi belajar siswa dan hasil tes kemampuan penalaaaran matematis.

\section{Teknik Analisis Data}

Indikator kriteria keberhasilan adalah suatu kinerja yang digunakan untuk melihat tingkat keberhasilan dari kegiatan penelitian tindakan kelas dalam meningkatkan atau memperbaiki mutu proses belajar mengajar di kelas. Dalam hal ini yang digunakan untuk menentukan keberhasilan pelaksanaan model pembelajaran yaitu peningkatan motivasi belajar siswa setelah mengikuti pelaksanaan model learning sycle $5 E$. Adapun kriteria keberhasilan didasarkan pada tercapainya peningkatan kemampuan penalaran matematis siswa melalui model learning sycle $5 E$ sebesar $20 \%$ dari siklus sebelumnya. Apabila kriteria tersebut tercapai maka siklus berhenti dan dapat dilakukan analisis data penelitian.

Cara pengambilan kesimpulan pada penelitian tindakan ini yaitu merangkum hasil observasi motivasi belajar siswa dan kegiatan model pembelajaran learning sycle 5E pada siklus I dan siklus II. Selanjutnya menyusun, mengolah, dan menyajikannya sesuai dengan kaidahkaidah ilmiah sehingga menjadi data yang bermakna. Berdasarkan data yang sudah diperoleh selanjutnya dapat disimpulkan pelaksanaan penelitian tindakatan kelas ini berhasil atau tidak berhasil dengan mengacu kepada indikator keberhasilan yang telah ditentukan.
Perhitungan capaian motivasi siswa masing-masing siswa menggunakan rumus sebagai berikut (Nugrahini, 2012: 67)

$$
\text { Capaian }=\frac{\text { Jumlah skor yang diperoleh }}{\text { Skor maksimum }} \times 100 \%
$$

Pedoman kriteria motivasi belajar siswa pada pembelajaran adalah sebagai berikut :

Tabel 1. Pedoman Kriteria Untuk Motivasi Siswa

\begin{tabular}{ll}
\hline \multicolumn{1}{c}{ Capaian } & \multicolumn{1}{c}{ Kriteria } \\
\hline $75 \%-100 \%$ & Tinggi \\
$50 \%-74,99 \%$ & Sedang \\
$25 \%-49,99 \%$ & Rendah \\
$0 \%-24,99 \%$ & Sangat Rendah \\
\hline
\end{tabular}

(Arikunto, 2007: 18)

\section{HASIL DAN PEMBAHASAN}

Penelitian Tindakan Kelas (PTK) ini terdiri dari dua siklus. Siklus I terdiri dari empat pertemuan dengan rincian, pada pertemuan pertama, kedua, dan ketiga peneliti menerapkan model pembelajaran yang digunakan sedangkan pada pertemuan keempat peneliti mengadakan tes akhir sebagai acuan dari hasil penerapan model tersebut. Sedangkan siklus II terdiri dari empat pertemuan dimana pertemuan pertama, kedua, dan ketiga peneliti menerapkan model pembelajarannya dan pertemuan keempat peneliti melakukan tes akhir siklus II tersebut. Penelitian dilakukan pada Kelas IX.1 dengan materi pokok Bangun Ruang Sisi Lengkung.

\section{Hasil Penelitian Siklus Pertama}

Berdasarkan hasil tes kemampuan penalaran matematis siswa dapat dilihat bahwa skor masing-masing indikator memiliki ketercapaian yang berbeda. Pada indikator pertama, yaitu "Mengklasifikasikan objek menurut sifat-sifat tertentu sesuai dengan konsepnya", banyak siswa telah dapat mengidentifikasi objek menurut sifat-sifatnya. Untuk indikator pertama ini diuji melalui soal no.1 dengan persentase kelas adalah 50\% sehingga dapat dikatakan bahwa 
kemampuan mengidentifikasi objek menurut sifat-sifatnya tercapai dengan kategori sedang. Skor yang paling banyak diperoleh siswa adalah 1 dengan persentasenya $43,75 \%$, sedangkan untuk siswa yang mendapat skor 0 adalah $15,63 \%$, yang mendapat skor 2 adalah $15,63 \%$, dan yang mendapat skor 3 adalah $25 \%$. Artinya, secara keseluruhan siswa mampu mengidentifikasi unsur-unsur BRSL berdasarkan sifatnya dengan cukup baik.

Indikator kemampuan penalaran matematis yang kedua adalah "Menyajikan konsep dalam berbagai bentuk representasi matematis". Indikator ini berkaitan dengan kemampuan siswa untuk merubah dan memodelkan permasalahan kontekstual kedalam model matematika atau diagram. Untuk indikator pertama ini diuji melalui soal no.2a dengan persentase kelas adalah 41,63\% sehingga dapat dikatakan bahwa kemampuan menerapkan konsep secara logis tercapai dengan kategori rendah. Banyak siswa yang mendapat skor 0 , yaitu dengan persentase 40,63\%, sedangkan yang mendapat skor 1 ada $18,75 \%$, skor 2 ada $15,63 \%$, dan skor 3 ada $25 \%$. Artinya, siswa belum mampu menyajikan penalaran matematis

Indikator ketiga yaitu "menerapkan konsep secara logis". Kemampuan ini berkaitan dengan kemampuan untuk menentukan algoritma atau konsep dari operasi biner pada himpunan. Untuk indikator ini diuji menggunakan 2 soal yaitu soal no. $2 \mathrm{~b}$ dan no.3. Persentase skor kelas untuk soal no.2b adalah 51,04\%. Banyak siswa yang mendapat skor 2, yaitu dengan persentase 43,75\%, sedangkan yang mendapatkan skor 0 ada $15,63 \%$, yang mendapat skor 1 ada $28,13 \%$, dan yang mendapat skor 3 ada $12,50 \%$. Sedangkan untuk soal no. 3 persentase secara keseluruhan adalah $36,46 \%$, dengan rincian yang mendapat skor 0 sebanyak $25 \%$, yang mendapat skor 1 sebanyak 45,88\%, yang mendapat skor 2 sebanyak 21,88\%, dan yang mendapat skor 3 sebanyak $6,25 \%$. Hal tersebut berarti kemampuan siswa dalam menerapkan konsep secara logis dapat dikatakan rendah.

Indikator keempat yaitu "Mengidentifikasi sifat-sifat operasi". Kemampuan ini berkaitan dengan kemampuan untuk bagaimana cara siswa untuk mengidentifikasi BRSL, serta cara menyelesaikan sifat tersebut. Persentase skor kelas pada indikator ini adalah $44,79 \%$. Dengan rincian yang mendapat skor 0 adalah $21,88 \%$, yang mendapat skor 1 adalah $40,63 \%$, yang mendapat skor 2 dan 3 adalah 18,75\%. Hal tersebut berarti kemampuan siswa dalam mengidentifikasi sifat-sifat masih belum maksimal terkuasai.

Secara keseluruhan rata-rata dari siklus I ini adalah 44,79 sehingga pada siklus I ini kemampuan penalaran matematis siswa belum terasah dengan maksimal. Siswa belum mampu untuk menguasai secara utuh materi BRSL tersebut dengan baik.

\section{Hasil Penelitian Siklus Kedua}

Berdasarkan hasil tes kemampuan penalaran matematis siswa dapat dilihat bahwa skor masing-masing indikator memiliki ketercapaian yang berbeda. Pada indikator pertama, yaitu "Mengklasifikasikan objek menurut sifatsifat tertentu sesuai dengan konsepnya", banyak siswa telah dapat mengidentifikasi objek menurut sifat-sifatnya. Untuk indikator pertama ini diuji melalui soal no.1 dengan persentase kelas adalah $80,21 \%$ dengan rincian skornya adalah tidak ada yang mendapat skor 0 , yang mendapat skor 1 ada $9,38 \%$, yang mendapat skor 2 ada $40,63 \%$, dan yang mendapat skor 3 ada 50\%. Sehingga dapat dikatakan bahwa kemampuan mengidentifikasi objek menurut sifatsifatnya tercapai dengan kategori sangat baik. Artinya, siswa telah mampu 
mengidentifikasi unsur-unsur BRSL dengan sangat baik.

Indikator kemampuan penalaran matematis yangkedua dan ketiga adalah "menerapkan konsep secara logis". Indikator ini berkaitan dengan kemampuan siswa untuk menerapkan atau menggunakan konsep yang ada untuk menyelesaikan permasalahan tersebut. Untuk indikator pertama ini diuji melalui soal no.2b dengan persentase kelas adalah $61,46 \%$ dengan rincian skornya adalah yang mendapat skor 0 ada $9,38 \%$, yang mendapat skor 1 ada $28,13 \%$, yang mendapat skor 2 dan 3 ada 31,25\%. Sehingga dapat dikatakan bahwa kemampuan menerapkan konsep secara logis tercapai dengan kategori baik. Artinya, siswa telah mampu menerapkan konsep operasi aljabar dengan baik.

Persentase skor kelas pada indikator ke empat ini adalah $63,54 \%$. Hal tersebut berarti kemampuan siswa dalam menyajikan konsep dalam berbagai bentuk representasi matematis dapat dikategorikan cukup baik. Telah banyak siswa yang mampu menyelesaikan permasalahan tersebut dengan baik. Hal ini dibuktikan dengan banyaknya siswa yang mendapat skor 3 yaitu $34,38 \%$, sedangkan untuk skor 0 ada $6,25 \%$, yang mendapat skor 1 ada $31,25 \%$, dan yang mendapat skor 2 ada $28,13 \%$.

Secara umum berdasarkan hasil tes dari siklus I ke siklus II. Rata-rata nilai siswa untuk kemampuan penalaran matematisnya telah mengalami peningkatan. Hal ini menunjukkan siswa telah termotivasi untuk mau belajar dengan baik dan penggunaan model pembelajaran learning sycle ini dapat meningkatkan motivasi belajar siswa dan juga dapat meningkatkan kemampuan penalaran siswa kelas IX.1 di SMPN 30 Padang.

\section{KESIMPULAN DAN SARAN Kesimpulan}

Kesimpulan yang dapat diambil dari penelitian tindakan kelas ini adalah sebagai berikut:

Pembelajaran dapat membuat siswa menjadi aktif, sehingga menumbuhkan minat dan meningkatkan hasil belajar siswa. Hasil ini juga menunjukan peningkatan keaktifan siswa sehingga hasil ini menunjukkan peningkatan kemampuan penalaran matematis siswa jauh meningkat dibandingkan dengan siswa pada pembelajaran yang tidak diberikan Learning Cycle $5 e$.

\section{Saran}

Berdasarkan hasil penelitian tindakan kelas yang telah dilaksanakan maka diajukan sejumlah saran. Saran yang perlu diperhatikan adalah:

1. Pelaksanaan pembelajaran matematika dengan model Learning Cycle $5 E$ dapat membuat siswa lebih aktif.

2. Pembelajaran matematika model Learning Cycle $5 E$ rutin dilakukan membuat anak jadi terbiasa, sehingga dapat meningkatkan hasil belajar siswa.

3. Model pembelajaran Learning Cycle $5 E$ sangat cocok digunakan pada semua materi matematika.

\section{DAFTAR PUSTAKA}

Akhadiah, dkk. (2010). Filsafat Ilmu Lanjutan. Jakarta: Kencana.

Arikunto, S. (2010). Prosedur Penelitian Suatu Pendekatan Praktik. Yogyakarta: Rineka Cipta.

Bakhtiar, A. (2004). Filsafat Ilmu.Jakarta: Raja Grafindo Persada.

Depdiknas. (2006).Standar Kompetensi dan Kompetensi Dasar. Jakarta: Direktorat Jenderal Manajemen Pendidikan Dasar dan Menengah.

Depdiknas. (2008). Panduan Pengembangan Bahan Ajar. Jakarta: Direktorat Jenderal Manajemen Pendidikan Dasar dan Menengah. 
Dahlan, J. A. (2004). Meningkatkan Kemampuan Penalaran dan Pemahaman Matematik Siswa Sekolah Lanjutan Pertama melalui PendekatanOpen-Ended. Disertasi Pada SPS UPI. Bandung: Tidak di terbitkan.

National council of Teachers of Mathematics (NCTM). (1989) Curiculum and Evaluation Standard For School Mathematics. [Online]. Tersedia:http://www.nctm.org. Di akses 5 Mai 2013.

(2000), Principle and Standar of Mathematics Education. [Online]. Tersedia: http://www.nctm.org Di akses 5 Mai 2013.

Syafaruddin \& Nasution, I. (2005). Manajemen Pembelajaran. Medan: Quantum Teaching.

Trends in International Mathematics and Science Study (TIMSS, 1999) 8th Grade Mathematics Concept and Mathematics Item. [online]: Tersedia:http:nces.ed.gov/timss/pdf/T IMSS8_Math_ConceptsItems.pdf

Third in International Mathematies and Science Study (TIMSS). TIMSS.(2003).8th_Grade

Mathematics Concept and Mathematics Item. [online]: Tersedia:http:nces.ed.gov/timss/pdf/T IMSS8 Math ConceptsItems.pdf

Trends in International Mathematics and Science Study (TIMSS, 1999) 8th_Grade Mathematics Concept and Mathematics Item. [online]: Tersedia:http:nces.ed.gov/timss/pdf/T IMSS8_Math_ConceptsItems.pdf

Trianto. (2009). Mendesain Model Pembelajaran Inovatif Progresif: Konsep, Landasan, dan Implementasinya pada Kurikulum Tingkat Satuan Pendidikan (KTSP). Jakarta: Prenada Media Group.

Turmudi.(2008). Landasan Filsafat dan Teori Pembelajaran Matematika Berparadigma Eksploratif dan
Investigatif. Jakarta: Leuser Cita Pustaka.

Warsono \& H. (2012). Pembelajaran Aktif : Teori dan Asesmen. Srabaya: Rosda.

Wena,M. (2008).Strategi Pembelajaran Inovatif Kontemporer. Jakarta: Bumi aksara. 